\title{
Prevalence of Past and Reactivated Viral Infections and Efficacy of Cyclosporine A as Monotherapy or in Combination in Patients with Psoriatic Arthritis-Synergy Study: A Longitudinal Observational Study
}

\author{
Delia Colombo, ${ }^{1}$ Sergio Chimenti, ${ }^{2}$ Paolo Grossi, ${ }^{3}$ Antonio Marchesoni, ${ }^{4}$ Sergio Di Nuzzo, ${ }^{5}$ \\ Vito Griseta, ${ }^{6}$ Anna Gargiulo, ${ }^{7}$ Aurora Parodi, ${ }^{8}$ Lucia Simoni, ${ }^{9}$ and Gilberto Bellia ${ }^{1}$ \\ ${ }^{1}$ Novartis Farma Italia, Origgio (Va), Italy \\ ${ }^{2}$ Policlinico Tor Vergata, Rome, Italy \\ ${ }^{3}$ Ospedale di Circolo e Fondazione Macchi, Varese, Italy \\ ${ }^{4}$ Istituto Ortopedico Pini, Milan, Italy \\ ${ }^{5}$ Azienda Ospedaliero-Universitaria, Parma, Italy \\ ${ }^{6}$ Ospedale Regionale F. Miulli, Acquaviva delle Fonti (BA), Italy \\ ${ }^{7}$ Azienda Ospedaliera Sant'Anna e San Sebastiano, Caserta, Italy \\ ${ }^{8}$ Ospedale San Martino, Genoa, Italy \\ ${ }^{9}$ MediData srl, Modena, Italy \\ Correspondence should be addressed to Delia Colombo; delia.colombo@novartis.com
}

Received 27 December 2013; Accepted 10 March 2014; Published 3 April 2014

Academic Editor: Giuseppe Valacchi

Copyright (C) 2014 Delia Colombo et al. This is an open access article distributed under the Creative Commons Attribution License, which permits unrestricted use, distribution, and reproduction in any medium, provided the original work is properly cited.

We have prospectively evaluated psoriatic arthritis (PsA) patients for (1) seropositivity for former viral infections and seroconversion and (2) efficacy of cyclosporine A (CsA) alone or in combination with other immunosuppressants in a time period of 12 months. Screening included HBV antibodies and antigens, HCV antibodies and RNA, HSV 1-2, HZV, EBV, and CMV IgG, and IgM, HHV-6 DNA, and HIV 1-2 antibodies. PsA was evaluated by the Psoriasis Area Severity Index (PASI), the Bath Ankylosing Spondylitis Disease Activity Index (BASDAI), and the Visual Analogue Scale (VAS). At baseline, 126 (56\%) out of 225 evaluable patients had 2 or more seropositivities indicative of former infections, and 31 patients (13.8\%) presented seropositivity for HCV, HBV, HSV-1 and -2, HHV-6, EBV, or parvovirus infection; one of them, positive for HBAg, was treated with lamivudine, while the remaining 30 received no specific treatment. None of the 31 patients developed virus reactivation. A reduction $(P<0.001)$ of PASI, BASDAI, and VAS scores was observed at 6 and 12 months. The treatment of PsA with CsA as monotherapy or in combination was safe and effective. In vitro experiments and clinical findings, including those from our study, suggest that CsA as monotherapy or in combination with biologics might be the treatment of choice in PsA HCV-positive patients.

\section{Introduction}

Psoriatic arthritis (PsA) is a disabling complication which occurs in $6 \%$ to $39 \%$ of psoriatic patients $[1,2]$. The clinical picture is characterized by skin and nail psoriasis associated with heterogeneous spondyloarthropathy, usually manifesting as synovitis, enthesitis, dactylitis, and spondylitis [3]. In most patients, the skin disease precedes musculoskeletal involvement. Obesity is a risk factor for the development of PsA in patients with psoriasis [4]. Its early recognition, diagnosis, and treatment can relieve pain and inflammation and, possibly, help prevent progressive joint involvement and damage [3]. Over the past years, advances have been made in the understanding of genetic and molecular mechanisms of PsA and its management [3]. 
Patients with PsA are often treated with systemic immunosuppressant agents (e.g., steroids, methotrexate, cyclosporine A, biologic drugs), which might increase the risk of reactivation of past infections or the acquisition of new infections. Such infections could possibly be life-threatening. Despite the influence of these treatments on the development of infections, data addressing this issue are scant.

Aims of this study were to evaluate, in a population of patients with PsA, (1) seropositivity for former viral infections or suggestive for acute viral infection, (2) efficacy of cyclosporine A (CsA) administered in routine clinical practice alone or in combination with other immunosuppressants in a time period of 12 months, and (3) the occurrence of adverse events during the study period.

\section{Patients and Methods}

The study was approved by the local Ethics Committee at each participating center and signed informed consent was obtained from participating patients. This was a crosssectional and longitudinal study (12 months), carried out in 238 consecutive patients with diagnosis of PsA performed within 8 years from baseline, treated for at least 3 months with CsA as monotherapy or in combination with one or more systemic drugs. The diagnosis of PsA was performed according to the CASPAR criteria [5]. Psoriasis was evaluated by the Psoriasis Area Severity Index (PASI) [6]. PsA was evaluated based on the joints involved, the patients' and the physicians' global assessment of the disease using the Visual Analogue Scale (VAS) [7]. The Bath Ankylosing Spondylitis Disease Activity Index (BASDAI) [8] was used to evaluate inflammation of the spine. Baseline screening for latent and acute viral infections included hepatitis B virus (HBV) antibodies (anti-HBs and anti-HBc) and surface antigen, hepatitis $\mathrm{C}$ virus (HCV) antibodies and RNA, herpes simplex virus 1-2 (HSV 1-2) IgG and IgM, herpes zoster virus (HZV) IgG and IgM, human herpes virus 6 (HHV-6) DNA, Epstein-Barr virus (EBV) IgG and IgM, human immunodeficiency virus 1-2 (HIV 1-2) antibodies, cytomegalovirus (CMV) IgG and IgM, and parvovirus B19 IgG and IgM. Follow-up visits were performed at 6 and 12 months to investigate new pathologies and treatments, evolution of PsA (PASI, VAS, and BASDAI), and occurrence of adverse events.

Data are reported as mean $\pm \mathrm{SD}$, median $\left(\mathrm{IQ}_{25-75}\right)$, or percentage, as appropriate. Changes in the PASI and BASDAI values at selected time points were compared using the paired $t$-test.

\section{Results}

3.1. Patients and Treatments. Two hundred thirty-eight patients with PsA were screened in 24 centers. Thirteen patients not fulfilling the inclusion criteria were excluded from the analysis which, therefore, was conducted on 225 patients at baseline. The number of patients evaluable at 6- and 12-month followups was 177 and 174, respectively. Eleven patients (4.9\%) had been vaccinated for $\mathrm{HB}$ and
TABLE 1: Demographic and clinical characteristics at baseline.

\begin{tabular}{|c|c|}
\hline \multicolumn{2}{|l|}{ Sex, number (\%) } \\
\hline Male & $121(54)$ \\
\hline Female & $104(46)$ \\
\hline \multicolumn{2}{|l|}{ Age (years, mean $\pm S D$ ) } \\
\hline Male & $48.9 \pm 12.8$ \\
\hline Female & $50.8 \pm 12.5$ \\
\hline \multicolumn{2}{|l|}{ Treating physician, number (\%) } \\
\hline Dermatologist & $166(73.8)$ \\
\hline Rheumatologist & $52(23.1)$ \\
\hline Both & $4(1.8)$ \\
\hline $\begin{array}{l}\text { Age at diagnosis of psoriasis } \\
\text { (years, mean } \pm \text { SD) }\end{array}$ & $38.3 \pm 15.6$ \\
\hline $\begin{array}{l}\text { Age at diagnosis of psoriatic arthritis } \\
\text { (years, mean } \pm \text { SD) }\end{array}$ & $47.6 \pm 12.4$ \\
\hline PASI, median $\left(\mathrm{IQ}_{25-75}\right)$ & $4.7(0.8-11.8)$ \\
\hline BASDAI, median $\left(\mathrm{IQ}_{25-75}\right)$ & $40.8(23.5-56.8)$ \\
\hline \multicolumn{2}{|l|}{$\begin{array}{l}\text { Classification according to joint } \\
\text { involvement, } \%^{1}\end{array}$} \\
\hline Monoarticular & $19(8.4)$ \\
\hline Oligoarticular & $81(36.0)$ \\
\hline Polyarticular & $92(41.0)$ \\
\hline Spondylotic & $36(16.0)$ \\
\hline Enthesic & $40(18)$ \\
\hline \multicolumn{2}{|l|}{ Comorbidities, no. (\%) } \\
\hline Cardiovascular & $62(27.6)$ \\
\hline Diabetes mellitus type 2 & $13(5.8)$ \\
\hline Diabetes mellitus type 1 & $4(1.8)$ \\
\hline Renal disease & $5(2.2)$ \\
\hline Cancer & $1(0.4)$ \\
\hline Hepatitis B & $1(0.4)$ \\
\hline Other & $49(21.8)$ \\
\hline
\end{tabular}

Data refer to 225 patients except for BASDAI (61 evaluable patients). PASI: Psoriasis Area Severity Index; BASDAI: Bath Ankylosing Spondylitis Disease Activity Index. ${ }^{1}$ Patients can be classified in more than one group.

were excluded from baseline and follow-up analysis for HBV seroconversion.

Demographic and clinical characteristics at baseline are reported in Table 1 . The most common type of psoriasis was psoriasis vulgaris (plaque psoriasis). As expected, PsA was equally distributed among males and females, and, on average, the diagnosis of psoriasis required less time than the diagnosis of PsA; the time between psoriasis and PsA diagnoses was 9.3 years $( \pm 13.6)$, on average. Median time $\left(\mathrm{IQ}_{25-75}\right)$ from the diagnosis of the disease to the first systemic treatment for psoriasis or PsA was 4 years $\left(\mathrm{IQ}_{25-75} 1-\right.$ 13). One hundred five patients $(46.7 \%)$ had comorbidities; cardiovascular comorbidities were observed in 62 patients $(27.6 \%)$.

Systemic, topic, and other treatments at baseline and follow-up visits are reported in Table 2. At baseline, all patients were treated with oral CsA for at least 3 months, 
TABLE 2: Description of treatments at baseline and at the end of study.

\begin{tabular}{|c|c|c|}
\hline & Baseline (number $=225)$ & From baseline to 12 -month followup (number $=174)$ \\
\hline \multicolumn{3}{|l|}{ Systemic treatments, number (\%) } \\
\hline Cyclosporine & $110(48.9)$ & $70(40.2)$ \\
\hline Cyclosporine + methotrexate & $36(16.0)$ & $26(14.9)$ \\
\hline Cyclosporine + biologic & $23(10.2)$ & $38(21.8)$ \\
\hline Cyclosporine + other systemic treatments & $45(20.0)$ & $27(15.5)$ \\
\hline m.d. & $11(4.9)$ & $13(7.5)$ \\
\hline \multicolumn{3}{|l|}{ Topic treatments, no. $(\%)^{1}$} \\
\hline Total number of patients treated & $175(77.8)$ & $103(59.2)$ \\
\hline No topic treatment & $47(20.9)$ & $68(39.1)$ \\
\hline m.d. & $3(1.3)$ & $3(1.7)$ \\
\hline Corticosteroids & $157(69.8)$ & $77(44.3)$ \\
\hline Vit D3 derivatives & $98(43.6)$ & $53(30.5)$ \\
\hline Retinoids & $27(12.0)$ & $8(4.6)$ \\
\hline PUVA & $5(2.2)$ & $2(1.1)$ \\
\hline UVB & $8(3.6)$ & $4(2.3)$ \\
\hline Laser & $1(0.4)$ & $1(0.6)$ \\
\hline Other & $15(6.7)$ & $21(12.1)$ \\
\hline Intra-articular injection & $5(2.2)$ & $6(3.4)$ \\
\hline
\end{tabular}

${ }^{1}$ Patients might have been treated with more than one topic treatment. m.d.: missing data.

$48.9 \%$ as systemic monotherapy, $16 \%$ in combination with methotrexate, and $10.2 \%$ in combination with biologic agents; $78 \%$ of patients received also topic treatments. During the study period there was a modest decrease in the use of CsA as both monotherapy and in combination with methotrexate, while a significant increase was observed in the combination CsA/biologic agents (Table 2). The study period was also characterized by a decrease in the frequency of topic therapy (from $78 \%$ at baseline to $59 \%$ at the end of the study).

3.2. Prevalence of Latent Viral Infections. At baseline, $56 \%$ of evaluable patients had 2 or more seropositivities indicative of former viral infections (Figure 1). The most frequent were VZV (95.3\%), HSV-1 (92.2\%), EBV (89.2\%), CMV (77\%), and HSV-2 (67\%). No subject showed HIV antibodies. None of these patients experienced reactivation or new onset viral infections or other infectious diseases during the following 12 months. A linear relationship was observed between the number of executed tests and infections (Pearson's correlation coefficient $=0.80865, P<0.0001)$.

3.3. Prevalence of Critical Viral Infections. At baseline, 31 patients (13.8\%) presented seropositivity for $\mathrm{HCV}, \mathrm{HBV}$, HSV-1 and -2, HHV-6, EBV, and parvovirus B19 (Table 3). One of them, positive for HBsAg, was treated with lamivudine, while the remaining 30 received no specific treatment or prophylaxis. In all these patients the viral infection was asymptomatic.

During the following 12 months all 31 patients continued their immunosuppressive treatment of PsA and none developed virus reactivation (Table 3). Two HCV-RNA-positive patients and one HBsAg-positive patient were negative after 12 months.

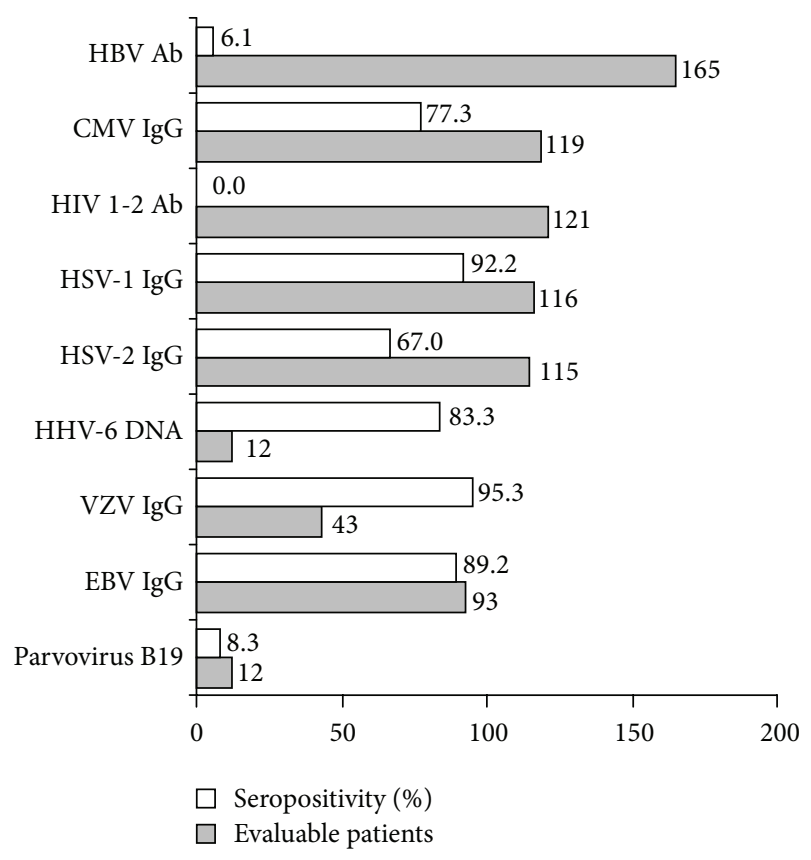

FIGURE 1: Chronic viral seropositivity (former viral infection) at baseline (\%, white bars) in evaluable patients (number, grey bars).

3.4. Evolution of Psoriasis and PsA during the Study Period. Evaluation of psoriasis and PsA during the study period was one of the secondary objectives of the study. PASI, VAS, and BASDAI were assessed at baseline, 6 and 12 months. A progressive and significant $(P<0.001$ versus baseline) reduction of PASI was observed at 6 and 12 months (Figure 2), indicating an improvement of psoriasis during the study period. 
TABLE 3: Description of patients with acute viral seropositivity.

\begin{tabular}{|c|c|c|c|c|}
\hline & Basal & $\begin{array}{l}\text { Number of patients who } \\
\text { developed a } \\
\text { virus-correlated disease }\end{array}$ & $\begin{array}{l}\text { Treatment of viral } \\
\text { seropositivity }\end{array}$ & $\begin{array}{c}\text { Systemic treatment of psoriatic } \\
\text { arthritis } \\
\text { during the study }\end{array}$ \\
\hline HCV RNA $(n=17)$ & 7 pos & 0 & No & $\begin{array}{c}5 \text { CsA; } 1 \text { CsA + steroid + methotrexate; } \\
1 \text { CsA + biologic }\end{array}$ \\
\hline HBsAg $(n=188)$ & 6 pos & 0 & 1 pt (lamivudine) & $\begin{aligned} 3 \mathrm{CsA} ; 2 \mathrm{CsA}+ & \text { MTX; } 1 \text { CsA + steroid } \\
& + \text { MTX }\end{aligned}$ \\
\hline HSV-1 IgM $(n=115)$ & 3 pos & 0 & No & $\begin{array}{c}1 \text { CsA; } 1 \text { CsA + steroid; } 1 \text { CsA + steroid } \\
+ \text { MTX }\end{array}$ \\
\hline HSV-2 IgM $(n=114)$ & 3 pos & 0 & No & $\begin{aligned} 1 \mathrm{CsA} ; 1 \mathrm{CsA}+\text { steroid; } 1 \text { CsA + steroid } \\
+ \text { MTX }\end{aligned}$ \\
\hline HHV-6 DNA $(n=12)$ & 10 pos & 0 & No & 7 CsA $; 3$ CsA + biologic \\
\hline EBV $\operatorname{IgM}(n=99)$ & 1 pos & 0 & No & $1 \mathrm{CsA}+$ steroid + biologic \\
\hline Parvovirus B59 IgM $(n=12)$ & 1 pos & 0 & No & $1 \mathrm{CsA}$ \\
\hline
\end{tabular}

CsA: cyclosporine A; MTX: methotrexate.

TABLE 4: Clinical assessment of psoriatic arthritis (PsA) and spondylitis in patients evaluable at baseline and at follow-up visits (median and IQR).

\begin{tabular}{lccc}
\hline & Baseline & 6 months & 12 months \\
\hline VAS, patients' global assessment (no. $=144)$ & $50(30-71.5)$ & $30(12.5-50)^{*}$ & $20(10-43)^{*}$ \\
VAS, physicians' global assessment (no. $=147)$ & $40(20-60)$ & $20(5-44)^{*}$ & $10(5-30)^{*}$ \\
BASDAI (no. $=61)$ & $40.5(24-60)$ & $21(7-38)^{*}$ & $20(5-38)^{*}$ \\
\hline
\end{tabular}

Patients' and physicians' global assessment was performed using the Visual Analogue Scale (VAS). ${ }^{*} P<0.0001$ versus baseline.

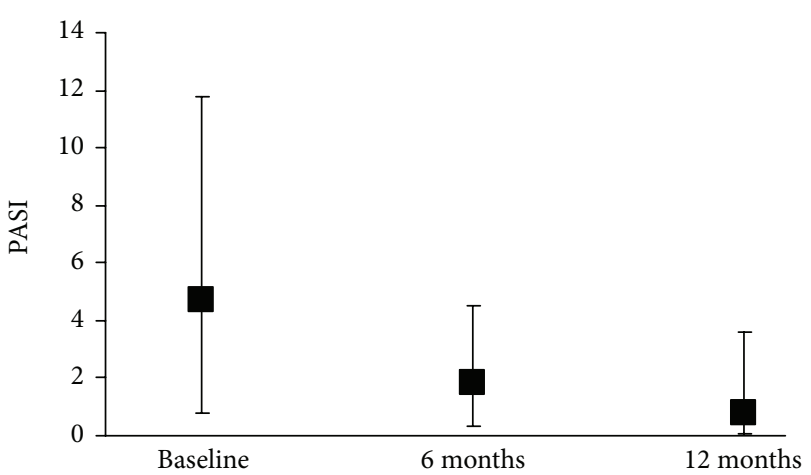

Figure 2: Psoriasis Area Severity Index (PASI) median values and $25^{\circ}-75^{\circ}$ percentiles during the study period in 153 patients evaluable at baseline and at follow-up visits.

Similarly, there was a decrease in the global activity of PsA during the study, shown by a decrease in both VAS and BASDAI $(P<0.0001$ versus baseline) (Table 4$)$, indicating an improvement in the musculoskeletal involvement of PsA.

3.5. Adverse Events. Eighteen adverse events were reported in 15 patients (Table 5). These adverse events were considered to be correlated with the treatment in 10 cases (to CsA in 9 cases and to infliximab in 1 case). One serious adverse event occurred (syncope); the patient fully recovered. No deaths occurred.

\section{Discussion}

4.1. Chronic and Acute Viral Seropositivity. PsA is an uncommon disease affecting $0.3-1 \%$ of the general population $[1,9]$. Therefore, the strength of this study is the high number of patients recruited and the execution of viral serologic tests not routinely performed in clinical practice. The primary endpoint of the study was to evaluate the prevalence of latent and acute viral infections in patients with PsA. Our data confirm previous observations from the literature indicating that patients with PsA are exposed to multiple viruses with increased prevalence compared to the normal population (Figure 1).

However, the most interesting finding of our study was that 31 patients with serologic findings suggestive of critical viral infections, despite immunosuppressive therapy, did not develop any virus-related clinical symptoms [10]. These patients were all chronically treated with CsA as monotherapy or in combination with other systemic immunosuppressants (Table 3). Although old and new immunosuppressive agents have the potential to induce virus reactivation, data from the literature are very limited in PsA, and the guidelines for the treatment of PsA do not provide therapeutic indications for patients with acute or latent viral infections [11]. However, the possibility that PsA patients also have viral infections is not negligible, and the administration of immunosuppressants to patients with moderate or severe forms can be necessary even in the presence of latent viral infections. 
TABLE 5: List of adverse events.

\begin{tabular}{|c|c|c|c|}
\hline Adverse event & Severity & Drug-related & $\begin{array}{l}\text { Systemic treatment of } \\
\text { psoriasis or psoriatic arthritis } \\
\text { concomitant to adverse event }\end{array}$ \\
\hline Increased creatinine and increased serum cholesterol & Mild & Yes, cyclosporine & Cyclosporine \\
\hline Increased creatinine & Mild & Yes, cyclosporine & Cyclosporine, sulfasalazine \\
\hline Gingival hyperplasia and gingival bleeding & Mild & Yes, cyclosporine & None \\
\hline Tremor & Mild & Yes, cyclosporine & Cyclosporine \\
\hline Burning urination & Mild & No & $\begin{array}{l}\text { Cyclosporine, methotrexate, } \\
\text { quinolones }\end{array}$ \\
\hline Urethritis & Mild & No & Fans \\
\hline Urethritis (Proteus mirabilis) & Mild & No & Fans \\
\hline Hypertension & Moderate & Yes, cyclosporine & Etanercept, cyclosporine \\
\hline Increased creatinine & Moderate & Yes, cyclosporine & Cyclosporine \\
\hline $\begin{array}{l}\text { Fatigue, stomatitis, gastrointestinal disorders, and } \\
\text { vomiting }\end{array}$ & Moderate & Yes, cyclosporine & Cyclosporine \\
\hline Nausea and vomiting & Moderate & Yes, cyclosporine & Cyclosporine, methotrexate \\
\hline Hypertension, altered liver Function tests & Moderate & Yes, cyclosporine & Cyclosporine \\
\hline Fever, sore throat, hyposmia, hypoacusia & Moderate & No & Methotrexate \\
\hline Postmicturition syncope & Moderate & No & Cyclosporine \\
\hline $\begin{array}{l}\text { Presyncopal episode preceded by autonomic problems } \\
\text { (sweating, dizziness, nausea) after several episodes of } \\
\text { diarrhea (enteritis) }\end{array}$ & Moderate & No & Cyclosporine \\
\hline Renal colic & Moderate & No & Cyclosporine, leflunomide \\
\hline Syncopal episode & Serious & UKN & Cyclosporine, methotrexate \\
\hline Outcomes of central vein occlusion & $\mathrm{UKN}$ & Yes, infliximab & $\begin{array}{l}\text { Infliximab, methotrexate, } \\
\text { cyclosporine }\end{array}$ \\
\hline
\end{tabular}

A few considerations can be made for HCV-positive PsA patients. The literature reports that systemic administration of corticosteroids in liver transplant recipients can increase $\mathrm{HCV}$ infectivity and exacerbate underlying viral infections $[12,13]$; therefore, corticosteroids should probably be avoided in PsA HCV-positive patients. On the contrary, in vitro studies have shown that $\mathrm{CsA}$ inhibits $\mathrm{HCV}$ replication by inhibiting cyclophilin B [14-16]. Moreover, patients treated with CsA after liver transplantation have lower HCV titers and reduced frequency of deaths or graft losses than patients treated with tacrolimus $[17,18]$.

Few cases of patients with PsA and HCV treated with CsA are reported in the literature. Miura et al. [19] described 4 patients with dermatologic diseases and HCV infection treated with CsA: in 3 cases, CsA was safe and it reduced HCV-RNA load and serum liver enzymes; the fourth patient showed a modest increase in alanine aminotransferases (ALT) levels but no change in blood HCV-RNA load. Galeazzi et al. [20] used CsA in 20 patients with rheumatologic disorders (4 with PsA) and concomitant HCV infection; they reported that HCV RNA load decreased significantly after 6 months. Giannitti et al. [21] treated 7 patients affected by rheumatoid arthritis and HCV infection with CsA and anti-TNF-alpha in combination and found that HCV RNA decreased significantly.

Our results support these earlier observations. An interesting and unexpected finding of our study was that two
HCV- RNA-positive patients at baseline evaluation were negative after 12 months of treatment with CsA.

4.2. Efficacy during Routine Clinical Practice. During the 12 -month period of the study, we observed a progressive improvement in our patients' cutaneous and musculoskeletal clinical picture. We hypothesize the improvement to have been related in part to the progressive therapeutic effect of CsA and, in part, to the increased number of patients who received biologics in combination with CsA.

\section{Conclusions}

Our study shows that PsA patients have a higher prevalence of viral seropositivity than the healthy population. Systematic screening for infections could improve identification of PsA patients at risk of developing active infections. In our patients, the treatment of PsA with CsA as monotherapy or in combination was effective and safe. In vitro experiments and clinical findings [22], including those obtained in our study, suggest that CsA as monotherapy or in combination with biologics might be the treatment of choice in HCV-positive patients if PsA needs systemic treatment, but caution and close laboratory and clinical monitoring are necessary prior to and during treatment. 


\section{Conflict of Interests}

Delia Colombo is a part-time employee of Novartis Farma Italy and received grants from Allergan and Aventis. Sergio Chimenti has received advisory/speaker honoraria and/or research funding from Abbvie, MSD, Novartis, and Pfizer. Paolo Grossi has received advisory/speaker honoraria and/or research funding from Novartis, Pfizer, MSD, Biotest, Astrazeneca, Gilead, and Astellas. Antonio Marchesoni has received advisory and speaker honoraria from Novartis. Sergio Di Nuzzo, Vito Griseta, and Anna Gargiulo have no conflict of interest. Aurora Parodi has received advisory/speaker honoraria and/or research funding from Abbvie, Almirall, Galderma, Leo Pharma, MSD, Novartis, Pfizer, and Shire. Lucia Simoni is an employee of Medidata srl, Italy. Gilberto Bellia is an employee of Novartis Farma Italy.

\section{Acknowledgments}

On behalf of the SYNERGY study group, Synergy Study Group included D. Casanova (Parma), V. Griseta (Bari), S. Chimenti (Rome), A. Gargiulo (Caserta), A. Parodi (Genoa), F. Ayala (Naples), F. Bardazzi (Bologna), G. Camplone (Rome), R. Foti (Catania), P. G. Calzavara-Pinton (Brescia), S. Donelli (Piacenza), N. Aste (Cagliari), C. Lauriti (Pescara), G. Cruciani (Rome), S. Calvieri (Rome), A. G. Galluccio (Benevento), C. Meschini (Viterbo), G. A. Vena (Bari), G. Altomare (Milan), P. Frugiuele (Cosenza), C. Giannitti (Siena), M. Govoni (Ferrara), P. P. Sainaghi (Novara), and G. Valenti (Catanzaro). The authors thank Roberto Imberti who provided assistance with English language editing.

\section{References}

[1] P. Mease, "Management of psoriatic arthritis: the therapeutic interface between rheumatology and dermatology," Current Rheumatology Reports, vol. 8, no. 5, pp. 348-354, 2006.

[2] F. Salaffi, R. de Angelis, W. Grassi et al., "Prevalence of musculoskeletal conditions in an Italian population sample: results of a regional community-based study. I. The MAPPING study," Clinical and Experimental Rheumatology, vol. 23, no. 6, pp. 819-828, 2005.

[3] P. J. Mease, "Psoriatic arthritis: update on pathophysiology, assessment and management," Annals of the Rheumatic Diseases, vol. 70, supplement 1, pp. i77-i84, 2011.

[4] T. J. Love, Y. Zhu, Y. Zhang et al., "Obesity and the risk of psoriatic arthritis: a population-based study," Annals of the Rheumatic Diseases, vol. 71, pp. 1273-1277, 2012.

[5] W. Taylor, D. Gladman, P. Helliwell, A. Marchesoni, P. Mease, and H. Mielants, "Classification criteria for psoriatic arthritis: development of new criteria from a large international study," Arthritis and Rheumatism, vol. 54, no. 8, pp. 2665-2673, 2006.

[6] T. Fredriksson and U. Pettersson, "Severe psoriasis-oral therapy with a new retinoid," Dermatologica, vol. 157, no. 4, pp. 238244, 1978.

[7] G. A. Hawker, S. Mian, T. Kendzerska, and M. French, "Measures of adult pain: visual Analog Scale for Pain (VAS Pain), Numeric Rating Scale for Pain (NRS Pain), McGill Pain Questionnaire (MPQ), Short-Form McGill Pain Questionnaire (SF-MPQ), Chronic Pain Grade Scale (CPGS), Short Form-36
Bodily Pain Scale (SF-36 BPS), and Measure of Intermittent and Constant Osteoarthritis Pain (ICOAP)," Arthritis Care and Research, vol. 63, supplement 11, pp. S240-S252, 2011.

[8] S. Garrett, T. Jenkinson, L. G. Kennedy, H. Whitelock, P. Gaisford, and A. Calin, "A new approach to defining disease status in ankylosing spondylitis: the bath ankylosing spondylitis disease activity index," Journal of Rheumatology, vol. 21, no. 12, pp. 2286-2291, 1994.

[9] V. Chandran, "Epidemiology of psoriatic arthritis," Journal of Rheumatology, vol. 36, no. 2, pp. 213-215, 2009.

[10] D. Vassilopoulos and L. H. Calabrese, "Risks of immunosuppressive therapies including biologic agents in patients with rheumatic diseases and co-existing chronic viral infections," Current Opinion in Rheumatology, vol. 19, no. 6, pp. 619-625, 2007.

[11] L. Gossec, J. S. Smolen, C. Gaujoux-Viala et al., "European league against rheumatism recommendations for the management of psoriatic arthritis with pharmacological therapies," Annals of the Rheumatic Diseases, vol. 71, no. 1, pp. 4-12, 2012.

[12] S. Ciesek, E. Steinmann, M. Iken et al., "Glucocorticosteroids increase cell entry by hepatitis C virus," Gastroenterology, vol. 138, no. 5, pp. 1875-1884, 2010.

[13] S. Ciesek and H. Wedemeyer, "Immunosuppression, liver injury and post-transplant HCV recurrence," Journal of Viral Hepatitis, vol. 19, no. 1, pp. 1-8, 2012.

[14] K. Watashi, M. Hijikata, M. Hosaka, M. Yamaji, and K. Shimotohno, "Cyclosporin A suppresses replication of hepatitis C virus genome in cultured hepatocytes," Hepatology, vol. 38, no. 5, pp. 1282-1288, 2003.

[15] M. Nakagawa, N. Sakamoto, Y. Tanabe et al., "Suppression of hepatitis $\mathrm{C}$ virus replication by cyclosporin $\mathrm{A}$ is mediated by blockade of cyclophilins," Gastroenterology, vol. 129, no. 3, pp. 1031-1041, 2005.

[16] F. Yang, J. M. Robotham, H. B. Nelson, A. Irsigler, R. Kenworthy, and H. Tang, "Cyclophilin A is an essential cofactor for hepatitis $\mathrm{C}$ virus infection and the principal mediator of cyclosporine resistance in vitro," Journal of Virology, vol. 82, no. 11, pp. 52695278, 2008.

[17] G. Levy, F. Villamil, D. Samuel et al., "Results of LIS2T, a multicenter, ramdomized study comparing cyclosporine microemulsion with $\mathrm{C} 2$ monitoring and tacrolimus with $\mathrm{C} 0$ monitoring in de novo liver transplantation," Transplantation, vol. 77, no. 11, pp. 1632-1638, 2004.

[18] G. Levy, G. L. Grazi, F. Sanjuan et al., "12-month followup analysis of a multicenter, randomized, prospective trial in de novo liver transplant recipients (LIS2T) comparing cyclosporine microemulsion (C2 monitoring) and tacrolimus," Liver Transplantation, vol. 12, pp. 1464-1472, 2006.

[19] H. Miura, Y. Itoh, Y. Matsumoto et al., "Long-term administration of cyclosporin A to HCV-antibody-positive patients with dermatologic diseases," International Journal of Dermatology, vol. 38, no. 4, pp. 310-314, 1999.

[20] M. Galeazzi, F. Bellisai, C. Giannitti, S. Manganelli, G. Morozzi, and G. D. Sebastiani, "Safety of cyclosporin A in HCV-infected patients: Experience with cyclosporin A in patients affected by rheumatological disorders and concomitant HCV infection," Annals of the New York Academy of Sciences, vol. 1110, pp. 544549, 2007.

[21] C. Giannitti, M. Benucci, R. Caporali et al., "Efficacy and safety of anti-TNF- $\alpha$ therapy combined with cyclosporine a in patients with rheumatoid arthritis and concomitant hepatitis $\mathrm{C}$ 
virus infection," International Journal of Immunopathology and Pharmacology, vol. 22, no. 2, pp. 543-546, 2009.

[22] C. Giannitti, I. Fineschi, B. Frediani, A. Fioravanti, and M. Galeazzi, "Efficacy and safety of tocilizumab combined with cyclosporine $\mathrm{A}$ in a patient with rheumatoid arthritis and concomitant chronic hepatitis C virus infection," Clinical and Experimental Rheumatology, vol. 31, article 816, 2013. 


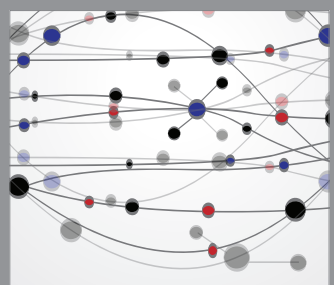

The Scientific World Journal
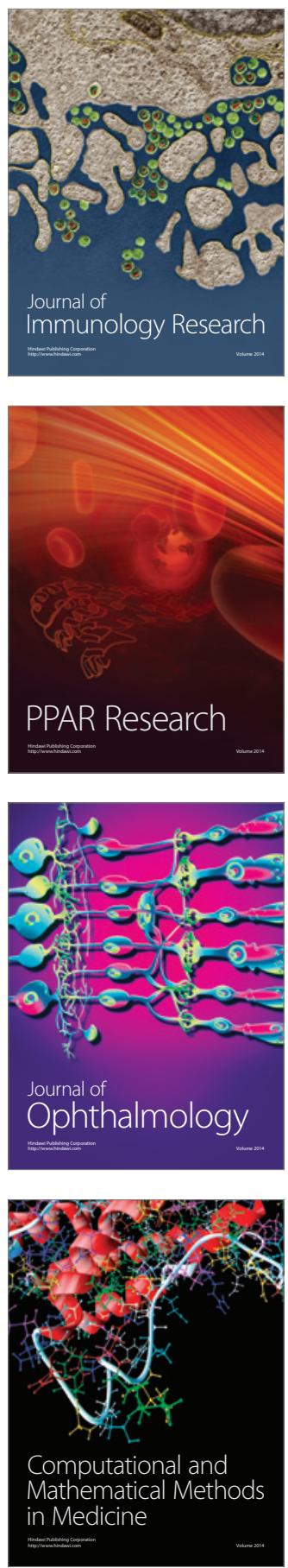

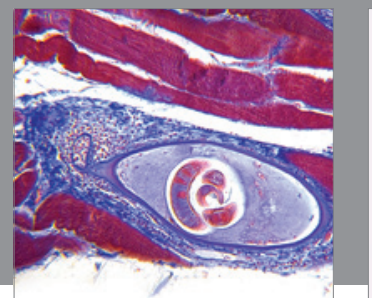

Gastroenterology

Research and Practice
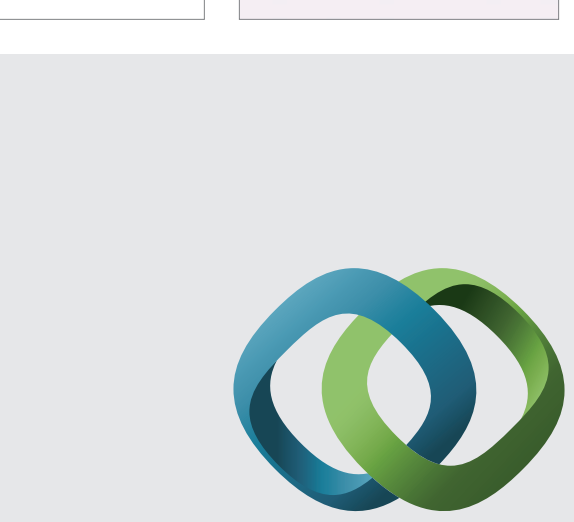

\section{Hindawi}

Submit your manuscripts at

http://www.hindawi.com
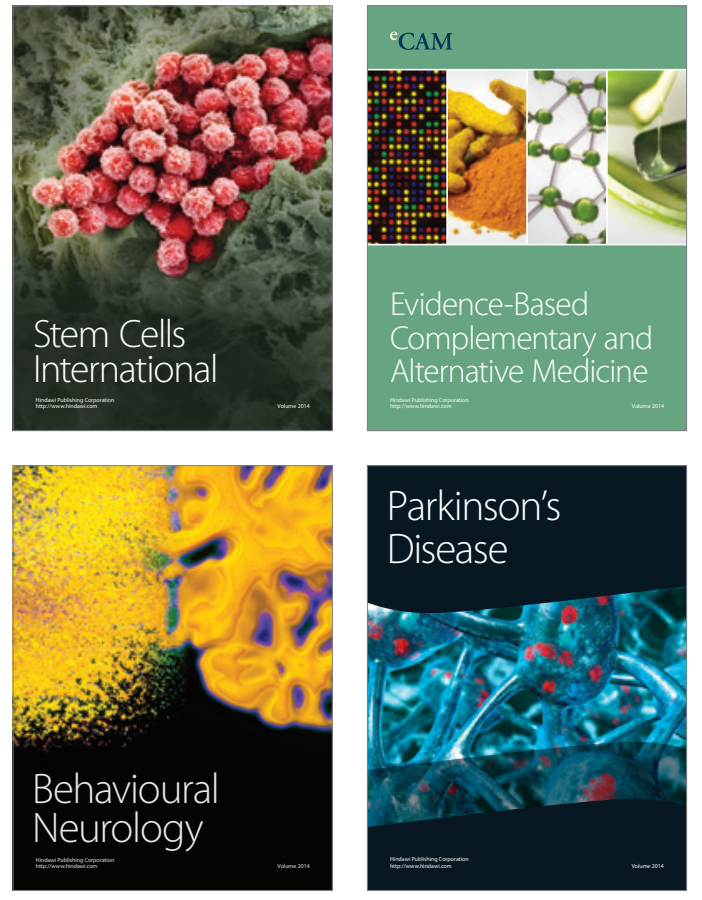
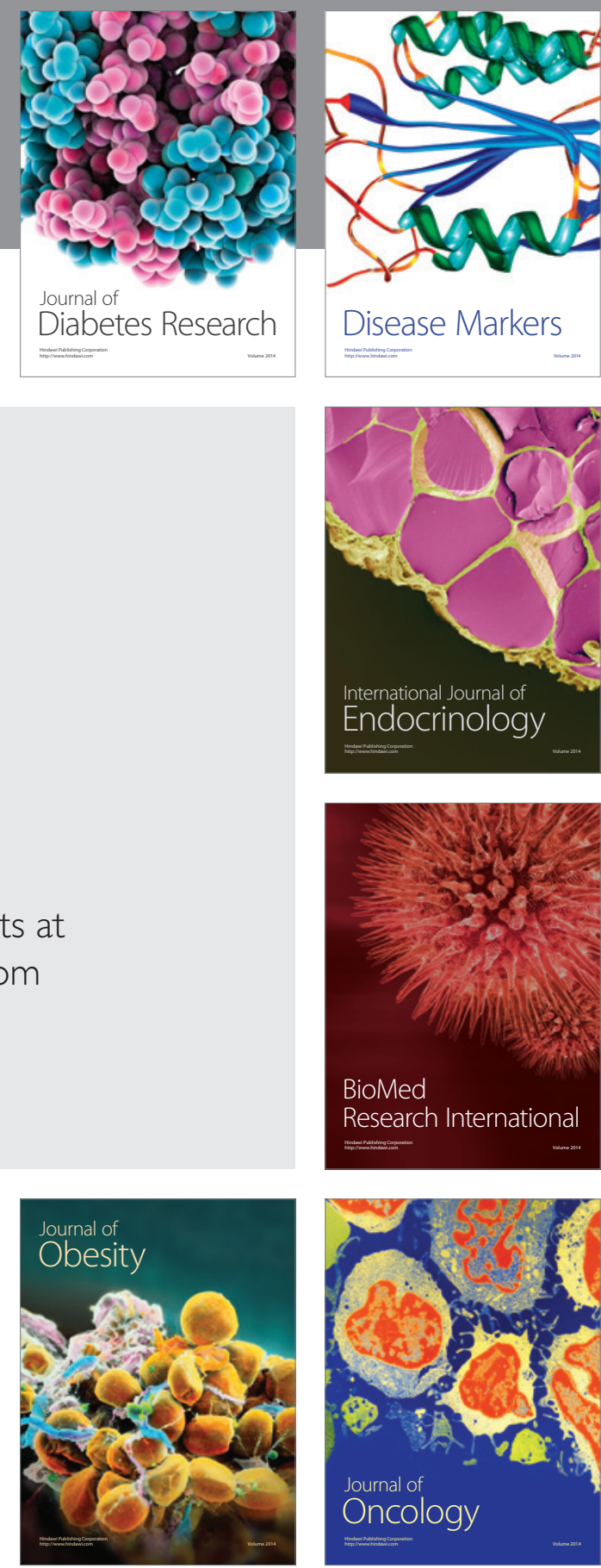

Disease Markers
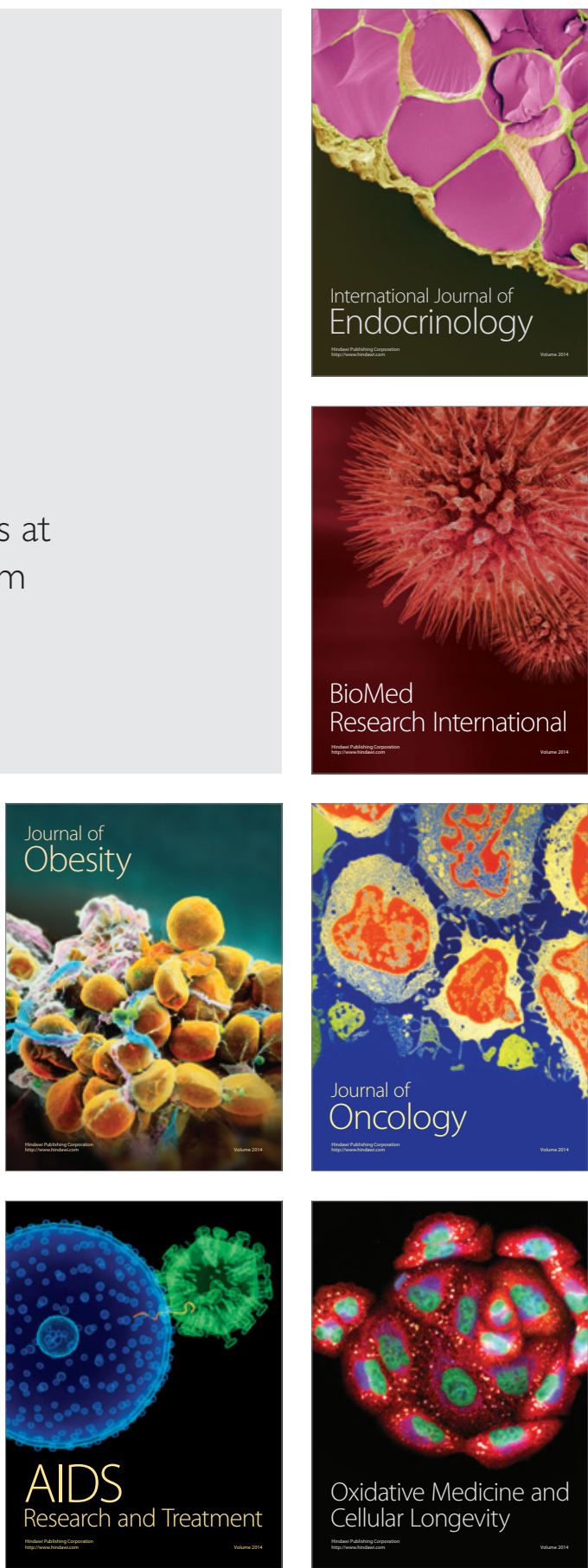